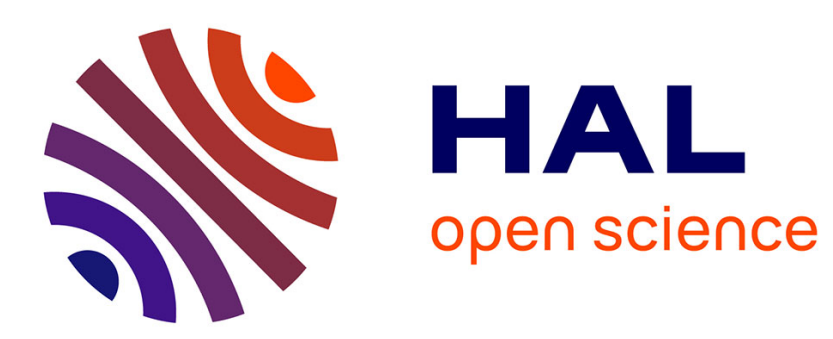

\title{
Strain and retrogression partitioning explain long-term stability of crustal roots in stable continents
}

Bénédicte Cenki-Tok, P. F. Rey, D. Arcay

\section{To cite this version:}

Bénédicte Cenki-Tok, P. F. Rey, D. Arcay. Strain and retrogression partitioning explain long-term stability of crustal roots in stable continents. Geology, 2020, 48 (7), pp.658-662. 10.1130/G47301.1. hal-02547410v2

\section{HAL Id: hal-02547410 https://hal.umontpellier.fr/hal-02547410v2}

Submitted on 23 Nov 2020

HAL is a multi-disciplinary open access archive for the deposit and dissemination of scientific research documents, whether they are published or not. The documents may come from teaching and research institutions in France or abroad, or from public or private research centers.
L'archive ouverte pluridisciplinaire HAL, est destinée au dépôt et à la diffusion de documents scientifiques de niveau recherche, publiés ou non, émanant des établissements d'enseignement et de recherche français ou étrangers, des laboratoires publics ou privés. 
$1{ }^{1}$ GSA Data Repository item 2020xxx, Table DR1 (thermal and mechanical parameters),

2 Figure DR1 (slow modeling results), Figure DR2 (fast modeling results), and the Python

3 input file (Script-G47301 285-Cenki-Tok-etal.ipynb), is available online at

4 http://www.geosociety.org/datarepository/2020/, or on request from

5 editing@geosociety.org.

$7 \quad$ Strain and retrogression partitioning explain long-term

8 stability of crustal roots in stable continents

9 B. Cenki-Tok ${ }^{1,2} *$ P.F. Rey $^{2}$ and D. Arcay ${ }^{1}$

$10{ }^{1}$ Géosciences Montpellier, Université de Montpellier, CNRS, 34095 Montpellier cedex 5,

11 France

$12{ }^{2}$ Earthbyte Research Group, ARC ITRH Basin GENESIS Hub, School of Geosciences,

13 University of Sydney, Sydney, New South Wales 2006, Australia

14 *E-mail: benedicte.cenki-tok@umontpellier.fr

\section{ABSTRACT}

16 Away from tectonically active regions, the continental crust has an average

17 thickness of $40 \pm 1 \mathrm{~km}$. Yet, it shows a remarkable variability from 25 to $65 \mathrm{~km}$,

18 comparable to that of the most tectonically active regions. Here, we consider the problem

19 of the formation and preservation of anomalous deep crustal roots in stable

20 intracontinental regions. Using two-dimensional thermomechanical experiments, we

21 show that the interplay between partial melting, the formation of garnet-pyroxene-bearing

22 rocks, and their strain rate-dependent retrogression result in the preservation of thick and

23 strong crustal roots. We argue that it is the partitioning into narrow regions of strain,

24 retrogression, and weakening coupled into a positive feedback loop that explains why 
25 strong high-grade crustal roots remain largely immune to gravitational stresses and are

26 able to persist over hundreds of millions of years.

\section{INTRODUCTION}

28 The crust-mantle transition is generally well-defined on geophysical images,

29 enabling detailed knowledge of crustal thickness at global and regional scales (Prodehl et

30 al., 2013). Discarding tectonically active regions, the thickness of the stable continental

31 crust has a global average of $\sim 40 \mathrm{~km}( \pm 1 \mathrm{~km}$ error on the calculated average crustal

32 thickness) (Christensen and Mooney, 1995; Fig. 1A). Yet, crustal root anomalies as much

33 as $65 \mathrm{~km}$ deep exist in all stable continents (e.g., Szwillus et al., 2019) from cratonic

34 regions such as the Baltic and Canadian Shields (Cook et al. 2010; Artemieva and Thybo,

35 2013; Fig. 1B) to Proterozoic and Paleozoic terranes such as Antarctica and Australia

36 (Salmon et al., 2012; An et al., 2015; Ebbing et al., 2018; Fig. 1C). Some of these crustal

37 roots have been interpreted as inherited regions of thick orogenic crust (e.g., Fischer,

38 2002; Studinger et al., 2004), others as mantle-derived mafic roots accreted below a

39 continental crust of normal thickness (e.g., Thybo and Artemieva, 2013). In both cases,

40 we expect that the enhanced heat flow would thermally weaken the deep crust, enabling

41 efficient viscous flow to relax gradients of crustal thickness and to flatten the Moho on a

42 regional scale (Clark and Royden, 2000; Beaumont et al., 2001; Nábělek et al., 2009; Rey

43 et al., 2010). Hence, the persistence over hundreds of millions of years of thick crustal

44 roots poses an intriguing problem. Although high heat flow produces migmatites and

45 granites that contribute to the transient weakening of the deep continental crust, it also

46 produces drier and stronger garnet-pyroxene rocks such as granulites (e.g., Jackson et al.,

47 2004). Upon cooling, hydration, and deformation, these stronger rocks may be 
48 retromorphosed into weaker amphibolitic gneisses. Here, we explore through two-

49 dimensional (2-D) thermomechanical experiments how the interplay between mechanical

50 weakening due to partial melting, strengthening and density increase due to the

51 crystallization of garnet-pyroxene assemblages, and post-orogenic weakening due to

52 retrogression may impact the long-term crustal thickness. Our results suggest that thick

53 crustal root anomalies could be the remnants of dry garnet-pyroxene-bearing rocks that

54 survived post-orogenic extension and retrogression. These garnet-pyroxene-bearing

55 crustal-scale boudins strengthen the lower crust and reduce its capacity to flow. Our

56 experiments are a first step toward explaining why relaxed orogenic crust may maintain

57 heterogeneities in crustal thickness hundreds of millions of years after orogeny has

58 ceased.

\section{NUMERICAL EXPERIMENTS, CODE, AND MODEL SETUP}

60 Our 2-D thermomechanical experiments consider a 360-km-wide orogenic plateau

61 with a 70-km-thick crust (i.e., the thickness of the Tibetan Plateau; Nábělek et al., 2009)

62 above $40 \mathrm{~km}$ of mantle (Fig. 2). A layer of air-like material with low viscosity and low

63 density is imposed on top of the crust to accommodate the development of surface

64 topography. The plateau experiences extensional deformation as the crust returns to a

65 normal thermomechanical state. Extensional-velocity boundary conditions are imposed

66 on both vertical walls of the model. We have tested slow $\left(0.18 \mathrm{~cm} \mathrm{yr}^{-1}\right)$ and fast $(1.8 \mathrm{~cm}$

$67 \mathrm{yr}^{-1}$ ) velocities, delivering a strain rate averaged over the length of the model of $3 \times 10^{-16}$

$68 \mathrm{~s}^{-1}$ and $3 \times 10^{-15} \mathrm{~s}^{-1}$ respectively. Horizontal boundaries of the model are free slips. The

69 thermal properties of the material combined with constant basal heat flow and constant

70 top temperature deliver an initial steady-state geotherm leading to a Moho temperature of 
$71 \sim 900{ }^{\circ} \mathrm{C}$ (Fig. 2). We select from the literature plausible visco-plastic parameters (see the

72 GSA Data Repository ${ }^{1}$ ) so the mechanical behavior of the modeled lithosphere depends

73 on temperature, strain rate, deviatoric stress, and accumulated strain. Details of modeling

74 procedures, rheological and thermal parameters, as well as the input Python script are

75 available in the Data Repository.

76 In order to explore the interplay between partial melting, the formation of stronger

77 garnet-pyroxene-bearing rocks, and their retrogression into weaker amphibolite facies

78 rocks, we parameterize three first-order metamorphic phase transitions. The first phase

79 change simulates partial melting and its feedback on density, viscosity, and temperature

80 (Rey et al., 2009; see the Data Repository). A second phase change with feedback on

81 density and viscosity occurs at temperature $T=777^{\circ} \mathrm{C}$ to simulate prograde amphibolite

82 to garnet-pyroxene rock reaction (Philpotts and Ague, 2009). Finally, a third phase

83 change with feedback on density and viscosity accounts for the retrogression of garnet-

84 pyroxene-bearing rocks back into amphibolite facies rocks. This third phase change

85 occurs at $T=777^{\circ} \mathrm{C}$ as well and for a strain rate $\geq 10^{-14} \mathrm{~s}^{-1}$. Our model implicitly

86 assumes that water is available. Therefore, retrogression is contingent upon strain rate,

87 which simulates the metastability of dry high-grade rocks during exhumation. This strain-

88 rate threshold is in the range of expected strain rates measured in orogenic shear zones

89 (Sassier et al., 2009; Boutonnet et al., 2013; Fagereng and Biggs, 2019). Rock solidus

90 depends on rock fertility and availability of fluid. Hence, we have tested different solidii

91 for the continental crust and the garnet-pyroxene-bearing rocks (Data Repository) in the

92 range commonly accepted for these rock types. For the continental crust, we have tested a

93 solidus representative of fertile metapelites with a melting temperature at room pressure 
94 of $650{ }^{\circ} \mathrm{C}$ (Figs. 3A and 3B; White et al., 2001), and a solidus representative of less-

95 fertile rocks with a melting temperature at room pressure of $720^{\circ} \mathrm{C}$ (Fig. $3 \mathrm{C}$; Rey and

96 Müller, 2010). For the dry garnet-pyroxene-bearing crust, we use a melting temperature

97 at room pressure of $790{ }^{\circ} \mathrm{C}$ representative of refractory granulites (Cenki-Tok et al.,

98 2016). We use Underworld, a well-tested open-source finite-element code

99 (https://underworld2.readthedocs.io/), to solve the equations of conservation of

100 momentum, mass, and energy for an incompressible fluid on a Cartesian Eulerian mesh

101 (Moresi et al., 2007; Beucher et al., 2019).

\section{RESULTS}

103 When a slow divergent velocity is imposed $\left(0.18 \mathrm{~cm} \mathrm{yr}^{-1}\right)$, the crust thins

104 homogeneously, the Moho remains flat, and deformation is dominated by pure shear

105 strain whether melt and/or garnet-pyroxene rocks are present or not (Fig. DR1 in the Data

106 Repository). In contrast, under faster extensional velocities $\left(1.8 \mathrm{~cm} \mathrm{yr}^{-1}\right)$, the

107 experimental outcome depends on phase changes. When the formation of strong garnet-

108 pyroxene rocks is not allowed, partial melting makes the deep crust hot and mobile,

109 which allows the formation of a migmatitic dome (Fig. 3A). In the partially molten dome,

110 finite strain ellipses are strongly flattened, with a vertical long axis indicating the

111 presence of a vertical high-strain zone separating two sub-domes. This double-dome

112 geometry has been well documented (Rey et al., 2011, 2017; Korchinski et al., 2018).

113 Figures 3B and 3C show a different result when prograde garnet-pyroxene rock formation

114 and retrogression into amphibolite are allowed. In the case where retrogression does not

115 occur (Fig. DR2A), the crust thins homogeneously. As the formation of garnet-pyroxene

116 rocks strengthens the deep crust, its capacity to flow is much reduced and the upper crust 
117 remains mechanically coupled to the mantle. Extensional deformation is more distributed

118 and heterogeneous as documented by the crustal-scale pinch-and-swell strain pattern, as

119 well as the finite strain field imaged by the finite strain ellipses (Fig. 3B). As strain rate

120 controls the retrogression of garnet-pyroxene rocks (Figs. DR2B and DR2C), we observe

121 that retrogression is partitioned into the pinch regions where strain rate is higher, whereas

122 garnet-pyroxene pods are preferentially preserved in the swell regions where strain rate is

123 lower and below the threshold required to activate retrogression. Because retrogression

124 leads to weakening, favoring strain localization and therefore higher strain rates, there is

125 a positive feedback loop between strain rate, retrogression, and weakening. When the

126 crustal solidus is that of a fertile metapelite, portions of the lower crust are partially

127 molten and able to flow under gravitational stresses, whereas flow is inhibited in the

128 strong garnet-pyroxene rock pods (Fig. 3D). Raising the solidus temperature of the

129 continental crust by $70^{\circ} \mathrm{C}$ results in a similar outcome except that there are no more

130 partially molten domains within the continental crust (Fig. 3C). Because of the formation

131 of garnet-pyroxene rock pods, the Moho presents a winding geometry with crustal

132 thickness variations of as much as $50 \%$, from 35 to $53 \mathrm{~km}$. After $25 \%$ of extension and

133 thinning, we have left these experiments to thermally and mechanically relax over 180

134 m.y. under fixed boundary conditions (i.e., setting the kinematic boundary condition to 0

$\left.135 \mathrm{~cm} \mathrm{yr}^{-1}\right)$. We observe that the heterogeneity of crustal thickness persists throughout this

136 long cooling history.

\section{DISCUSSION}

138 Our numerical experiments suggest that strain rate-dependent retrogression that

139 typically localizes along ductile shear zones cutting through high-grade rocks may 
140 explain how remnants of thick and strong orogenic crust can survive orogenic collapse.

141 These regions can be $\sim 50 \%$ thicker than the adjacent crust and as narrow as a few tens of

142 kilometers across, and survive for hundreds of millions of years. Anomalous deep crustal

143 roots have been imaged in stable intracontinental regions all around the globe. In the

144 eastern Canadian Shield, for example, the Lithoprobe project

145 (https://lithoprobe.eos.ubc.ca/) has documented several crustal roots (Cook et al., 2010).

146 Below the Torngat orogen along the eastern Canadian Shield, a Paleoproterozoic crustal

147 root as much as $50 \mathrm{~km}$ deep, $15 \mathrm{~km}$ deeper that the average adjacent crust, and $\sim 80 \mathrm{~km}$

148 wide and $>200 \mathrm{~km}$ long has been imaged on seismic profiles (Fig. 1B; Funck and

149 Louden, 1999). It is interesting to note that this Paleoproterozoic crustal root is bounded

150 to the north and east by major shear zones (Cook et al., 2010). In the Baltic Shield, along

151 an Archean-Paleoproterozoic suture, the Moho reaches a depth of $\sim 60 \mathrm{~km}$ over a region

152 centered on southern Finland (Artemieva and Thybo, 2013). In central Australia, even

153 though this continent has been tectonically relatively stable for the past 300 m.y., crustal

154 roots reaching $65 \mathrm{~km}$ depth have been imaged as deep regions of diffuse reflectivity over

155 circular domains a few hundred kilometers in diameter (Fig. 1C; Kennett et al., 2011;

156 Salmon et al., 2012). In Antarctica, a series of crustal roots as much as $60 \mathrm{~km}$ deep have

157 been documented between Dronning Maud Land and Gamburtsev Subglacial Mountains

158 (An et al., 2015; Ebbing et al., 2018). In peninsular India, made up of Archean to

159 Paleozoic terranes, the Moho depth varies from $\sim 38 \mathrm{~km}$ below the southernmost tip of

160 India's Proterozoic Southern Granulite terrane, to $50 \mathrm{~km}$ below the Archean Dharwar

161 craton in semicircular regions $\sim 250 \mathrm{~km}$ in diameter (Reddy and Vijaya Rao, 2013; Das et

162 al., 2019). The structure and nature of the lower crust below the Southern Granulite 
163 terrane is heterogeneous, but because the middle and upper crust shows a constant

164 thickness of $20-25 \mathrm{~km}$, this variability must be accommodated by variation in thickness

165 of the lower crust (18-32 km; Das et al., 2019).

166 The gravimetric and seismic characteristics of these crustal roots suggest the

167 presence of garnet-pyroxene-bearing rocks. For example, in Canada, crustal roots

168 showing P-wave velocities $>7 \mathrm{~km} \mathrm{~s}^{-1}$ led Cook et al. (2010) to propose that in the

169 absence of later tectonic reworking, the variations in Moho depth originate solely from

170 rheological variations. In southern India, crustal roots display compressional-wave

171 velocities that are systematically $>7 \mathrm{~km} \mathrm{~s}^{-1}$ (Reddy and Vijaya Rao, 2013), and shear-

172 wave velocities between 4 and $4.2 \mathrm{~km} \mathrm{~s}^{-1}$ (Das et al., 2019). The contrasting density and

173 seismic characteristics between granitic rocks and/or amphibolite facies gneisses $(<2700$

$174 \mathrm{~kg} \mathrm{~m}^{-3}$ and $\left.<6.4 \mathrm{~km} \mathrm{~s}^{-1}\right)$ and higher-grade garnet-pyroxene-bearing rocks ( $>2800 \mathrm{~kg} \mathrm{~m}^{-3}$

175 and $>6.6 \mathrm{~km} \mathrm{~s}^{-1}$; Christensen and Mooney, 1995; Artemieva and Thybo, 2013) suggest

176 that deep crustal roots are made of the latter (Williams et al., 2014). This proposition is

177 compatible with the seismically diffuse boundary that is commonly observed between the

178 lower crust and the mantle (O'Reilly and Griffin, 2013). Because the petrophysical

179 properties of garnet-pyroxene-bearing rocks are intermediate between the ones of the

180 crust and the mantle, a garnet-pyroxene-rich lower crust would explain the seismic

181 properties of the transition between the crust and the mantle observed in Peninsular India

182 for example (Reddy and Vijaya Rao, 2013).

183 Importantly, in all of these examples, crustal roots are interpreted as inherited

184 remnants of ancient orogenic crust that have survived gravitational collapse and the

185 flattening of the Moho. We propose that these strong orogenic crustal roots owe their 
186 survival to the presence of retrogressed and therefore weaker adjacent crusts in which

187 deformation is strongly partitioned. The positive feedback loop between strain,

188 retrogression, and weakening insures that deformation remains localized into retrogressed

189 domains, isolating and protecting garnet-pyroxene-bearing pods that remain largely

190 immune to deformation.

\section{CONCLUSIONS}

192 In this study, we have explored through 2-D thermomechanical modeling how the

193 interplay between partial melting, the formation of garnet-pyroxene high-grade rocks, and

194 strain rate-dependent retrogression could explain the long-term preservation of deep

195 crustal roots in stable continents. Though 2-D experiments are sufficient to illustrate how

196 strain rate, retrogression, and weakening can explain the preservation of thick roots,

197 future work involving 3-D experiments will allow investigation of triclinic boundary

198 conditions. Our experiments show that following the formation of high-grade rocks in

199 deep orogenic crusts, extension is partitioned into regions where strain, retrogression, and

200 weakening are coupled into a positive feedback loop. This results in the preservation of

201 thick, dense, and strong garnet-pyroxene-rich pods, separated by retrogressed and

202 attenuated pinched regions. The strong high-grade pods form crustal-scale boudins that

203 are able to survive through the orogenic relaxation phase and over a duration of $>100$

204 m.y. As a result, the equilibrated orogenic crust preserves deep crustal roots similar to

205 those documented in all stable continents. These results are first steps toward

206 understanding of the feedback between metamorphic reactions and deformation. In the

207 future, 3-D models involving porous flow and surface processes will allow a more

208 detailed understanding of these systems. 
Publisher: GSA

Journal: GEOL: Geology

DOI:10.1130/G47301.1

\section{ACKNOWLEDGMENTS}

210 We acknowledge funding from the European Union's Horizon 2020 research and

211 innovation program under grant agreement 793978. This research was undertaken with

212 the assistance of resources from the National Computational Infrastructure (NCI),

213 through the National Computational Merit Allocation Scheme supported by the

214 Australian Government; the Pawsey Supercomputing Centre (Perth, Australia) with

215 funding from the Australian Government and the Government of Western Australia, and

216 support from the Australian Research Council through the Industrial Transformation

217 Research Hub grant ARC-IH130200012. We thank Julian Giordani and Romain Beucher

218 for their expert support with Underworld (https://underworld2.readthedocs.io/). We thank

219 Chris Clark for editorial handling, as well as Gregory Dumond and two anonymous

220 reviewers for their constructive reviews.

\section{REFERENCES CITED}

222 An, M., Wiens, D.A., Yue, Z., Mei, F., Nyblade, A.A., Kanao, M., Li, Y., Maggi, A., and

223 Lévêque, J.-J., 2015, S-velocity model and inferred Moho topography beneath the

224 Antarctic Plate from Rayleigh waves: Journal of Geophysical Research: Solid Earth,

$$
\text { v. 120, p. 359-383, https://doi.org/10.1002/2014JB011332. }
$$

226 Artemieva, I.M., and Thybo, H., 2013, EUNAseis: A seismic model for Moho and crustal

227 structure in Europe, Greenland, and the North Atlantic region: Tectonophysics,

228 v. 609 , p. 97-153, https://doi.org/10.1016/j.tecto.2013.08.004.

229 Beaumont, C., Jamieson, R.A., Nguyen, M.H., and Lee, B., 2001, Himalayan tectonics

230 explained by extrusion of a low-viscosity crustal channel coupled to focused surface

231 denudation: Nature, v. 414, p. 738-742, https://doi.org/10.1038/414738a. 
232 Beucher, R., et al., 2019, UWGeodynamics: A teaching and research tool for numerical

233 geodynamic modelling: Journal of Open Source Software, v. 4, 1136,

$234 \quad$ https://doi.org/10.21105/joss.01136.

235 Boutonnet, E., Leloup, P.H., Sassier, C., Gardien, V., and Ricard, Y., 2013, Ductile strain

236 rate measurements document long-term strain localization in the continental crust:

237 Geology, v. 41, p. 819-822, https://doi.org/10.1130/G33723.1.

238 Cenki-Tok, B., Berger, A., and Gueydan, F., 2016, Formation and preservation of biotite-

239 rich microdomains in high-temperature rocks from the Antananarivo Block,

240 Madagascar: International Journal of Earth Sciences, v. 105, p. 1471-1483,

$241 \quad$ https://doi.org/10.1007/s00531-015-1265-0.

242 Christensen, N.I., and Mooney, W.D., 1995, Seismic velocity structure and composition

243 of the continental crust: A global view: Journal of Geophysical Research, v. 100,

244 p. 9761-9788, https://doi.org/10.1029/95JB00259.

245 Clark, M.K., and Royden, L.H., 2000, Topographic ooze: Building the eastern margin of

246 Tibet by lower crustal flow: Geology, v. 28, p. 703-706,

$247 \quad$ https://doi.org/10.1130/0091-7613(2000)28<703:TOBTEM>2.0.CO;2.

248 Cook, F.A., White, D.J., Jones, A.G., Eaton, D.W.S., Hall, J., and Clowes, R.M., 2010,

249 How the crust meets the mantle: Lithoprobe perspectives on the Mohorovic

250 discontinuity and crust-mantle transition: Canadian Journal of Earth Sciences, v. 47,

251 p. $315-351$, https://doi.org/10.1139/E09-076.

252 Das, R., Ashish, and Saha, G.K., 2019, Crust and shallow mantle structure of south India

253 by inverting interpolated receiver function with surface wave dispersion: Journal of 
Asian Earth Sciences, v. 176, p. 157-167,

256 Ebbing, J., Hass, P., Ferraccioli, F., Pappa, F., Szwillus, W., and Bouman, J., 2018, Earth

257 tectonics as seen by GOCE_Enhanced satellite gravity gradient imaging: Scientific

258 Reports, v. 8, https://doi.org/10.1038/s41598-018-34733-9.

259 Fagereng, Å., and Biggs, J., 2019, New perspectives on 'geological strain rates'

260 calculated from both naturally deformed and actively deforming rocks: Journal of

261 Structural Geology, v. 125, p. 100-110, https://doi.org/10.1016/j.jsg.2018.10.004.

262 Fischer, K.M., 2002, Waning buoyancy in the crustal roots of old mountains: Nature, v. 417, p. 933-936, https://doi.org/10.1038/nature00855.

264 Funck, T., and Louden, K.E., 1999, Wide-angle seismic transect across the Torngat 265 Orogen, northern Labrador: Evidence for a Proterozoic crustal root: Journal of 266 Geophysical Research, v. 104, p. 7463-7480, https://doi.org/10.1029/1999JB900010.

267 Jackson, J.A., Austrheim, H., McKenzie, D., and Priestley, K., 2004, Metastability, 268 mechanical strength, and the support of mountain belts: Geology, v. 32, p. 625-628, 269 https://doi.org/10.1130/G20397.1.

270 Kennett, B.L.N., Salmon, M., Saygin, E. and the AusMoho Working Group, 2011, 271 AusMoho: The variation of Moho depth in Australia: Geophysical Journal 272 International, v. 187, p. 946-958, https://doi.org/10.1111/j.1365-246X.2011.05194.X.

273 Korchinski, M., Rey, P.F., Mondy, L., Teyssier, C., and Whitney, D.L., 2018, Numerical 274 investigation of deep-crust behavior under lithospheric extension: Tectonophysics, 275 v. 726, p. 137-146, https://doi.org/10.1016/j.tecto.2017.12.029. 
276 Moresi, L., Quenette, S., Lemiale, V., Meriaux, C., Appelbe, B., and Mühlhaus, H.-B.,

2772007 , Computational approaches to studying non-linear dynamics of the crust and

278 mantle: Physics of the Earth and Planetary Interiors, v. 163, p. 69-82,

279 https://doi.org/10.1016/j.pepi.2007.06.009.

280 Nábělek, J., Hetényi, G., Vergne, J., Sapkota, S., Kafle, B., Jiang, M., Su, H.P., Chen, J.,

281 Huang, B.S., and the Hi-CLIMB Team, 2009, Underplating in the Himalaya-Tibet

282 collision zone revealed by the Hi-CLIMB Experiment: Science, v. 325, p. 1371-

$283 \quad$ 1374, https://doi.org/10.1126/science.1167719.

284 O’Reilly, S.Y., and Griffin, W.L., 2013, Moho vs crust-mantle boundary: Evolution of an

285 idea: Tectonophysics, v. 609, p. 535-546,

$286 \quad$ https://doi.org/10.1016/j.tecto.2012.12.031.

287 Philpotts, A.R., and Ague, J.J., 2009, Principles of Igneous and Metamorphic Petrology:

288 Cambridge, UK, Cambridge University Press, 667 p., https://doi.org/10.1017/CBO9780511813429.

290 Prodehl, C., Kennett, B., Artemieva, I.M., and Thybo, H., 2013, 100 years of seismic

291 research on the Moho: Tectonophysics, v. 609, p. 9-44,

292 https://doi.org/10.1016/j.tecto.2013.05.036.

293 Reddy, P.R., and Vijaya Rao, V., 2013, Seismic images of the continental Moho of the

294 Indian shield: Tectonophysics, v. 609, p. 217-233,

295 https://doi.org/10.1016/j.tecto.2012.11.022.

296 Rey, P.F., and Müller, R.D., 2010, Fragmentation of active continental plate margins

297 owing to the buoyancy of the mantle wedge: Nature Geoscience, v. 3, p. 257-261,

298 https://doi.org/10.1038/ngeo825. 
Rey, P.F., Teyssier, C., and Whitney, D.L., 2009, Extension rates, crustal melting, and

$300 \quad$ core complex dynamics: Geology, v. 37, p. 391-394,

$301 \quad$ https://doi.org/10.1130/G25460A.1.

302 Rey, P.F., Teyssier, C., and Whitney, D.L., 2010, The limit of channel flow in orogenic

303 plateaux: Lithosphere, v. 2, p. 328-332, https://doi.org/10.1130/L114.1.

304 Rey, P.F., Teyssier, C., Kruckenberg, S.C., and Whitney, D.L., 2011, Viscous collision in

305 channel explains double domes in metamorphic core complexes: Geology, v. 39,

306 p. $387-390$, https://doi.org/10.1130/G31587.1.

307 Rey, P.F., Mondy, L., Duclaux, G., Teyssier, C., Whitney, D.L., Bocher, M., and Prigent,

$308 \quad$ C., 2017, The origin of contractional structures in extensional gneiss domes:

309 Geology, v. 45, p. 263-266, https://doi.org/10.1130/G38595.1.

310 Salmon, M., Kennett, B.L.N., Stern, T., and Aitken, A.R.A., 2012, The Moho in Australia

311 and New Zealand: Tectonophysics, v. 609, p. 288-298,

$312 \quad$ https://doi.org/10.1016/j.tecto.2012.07.009.

313 Sassier, C., Leloup, P.H., Rubatto, D., Galland, O., Yue, Y., and Lin, D., 2009, Direct

314 measurement of strain rates in ductile shear zones: A new method based on

315 syntectonic dikes: Journal of Geophysical Research, v. 114, B01406,

316 https://doi.org/10.1029/2008JB005597.

317 Studinger, M., Bell, R.E., Buck, W.G., Karner, G.D., and Blankenship, D.D., 2004, Sub-

318 ice geology inland of the Transantarctic Mountains in light of new aerogeophysical

319 data: Earth and Planetary Science Letters, v. 220, p. 391-408,

$320 \quad$ https://doi.org/10.1016/S0012-821X(04)00066-4. 
321 Szwillus, W., Afonso, J.C., Ebbing, J., and Mooney, W.D., 2019, Global crustal thickness

322 and velocity structure from geostatistical analysis of seismic data: Journal of

323 Geophysical Research: Solid Earth, v. 124, p. 1626-1652,

324 https://doi.org/10.1029/2018JB016593.

325 Thybo, H., and Artemieva, I.M., 2013, Moho and magmatic underplating in continental

326 lithosphere: Tectonophysics, v. 609, p. 605-619,

327 https://doi.org/10.1016/j.tecto.2013.05.032.

328 White, R.W., Powell, R., and Holland, T.J.B., 2001, Calculation of partial melting

329 equilibria in the system $\mathrm{Na}_{2} \mathrm{O}-\mathrm{CaO}-\mathrm{K}_{2} \mathrm{O}-\mathrm{FeO}-\mathrm{MgO}-\mathrm{Al}_{2} \mathrm{O}_{3}-\mathrm{SiO}_{2}-\mathrm{H}_{2} \mathrm{O}$

330 (NCKFMASH): Journal of Metamorphic Geology, v. 19, p. 139-153,

$331 \quad$ https://doi.org/10.1046/j.0263-4929.2000.00303.x.

332 Williams, M.L., Dumond, G., Mahan, K., Regan, S., and Holland, M., 2014, Garnet-

333 forming reactions in felsic orthogneiss: Implications for densification and

334 strengthening of the lower continental crust: Earth and Planetary Science Letters,

335 v. 405 , p. 207-219, https://doi.org/10.1016/j.epsl.2014.08.030.

\section{FIGURE CAPTIONS}

337 Figure 1. (A) Crustal thickness histogram for world shields extracted from CRUST 5.1

338 model (modified from https://earthquake.usgs.gov/data/crust/crust.php). (B) Interpolated

339 compressional-wave velocities across the Torngat orogen, northeastern Canada (modified

340 from Funck and Louden, 1999). (C) Interpolated Moho surfaces for Australia constructed

341 by interpolating weighted averages for each $0.5^{\circ} \times 0.5^{\circ}$ pixel (modified from Kennett et

342 al., 2011). 
344 Figure 2. Model geometry and initial conditions, as well as geotherm, viscosity, and

345 density profiles. Weak prismatic region dipping $45^{\circ}$ simulates detachment fault in upper

346 crust. Circles pattern superimposed on continental crust represents finite-strain ellipses.

348 Figure 3. Fast-velocity modeling results $\left(1.8 \mathrm{~cm} \mathrm{yr}^{-1}\right.$ extension speed $)$ at average strain

349 rate of $3 \times 10^{-15} \mathrm{~s}^{-1}$ and $25 \%$ extension. Colors are the same as in Figure 2. (Model A)

350 Only partial melting is allowed (garnet-pyroxene isograde and retrogression into

351 amphibolite are removed). (Model B) Partial melting, crystallization of garnet-pyroxene

352 assemblages, and retrogression are allowed. Temperature for transformation of

353 continental crust into garnet-pyroxene-rich rocks is $777^{\circ} \mathrm{C}$ (see text for explanation).

354 Reference temperatures for solidus of continental crust and garnet-pyroxene-rich crust are $355650{ }^{\circ} \mathrm{C}$ and $790{ }^{\circ} \mathrm{C}$, respectively. (Model C) Same as model B but temperature for

356 continental crust solidus is increased to $720^{\circ} \mathrm{C}$. (Model D) Zoom on model B illustrating

357 velocity field (black arrows) when boundary condition mimicking extension is removed

358 (after 2 m.y. of gravity forces operating), showing that partially molten crust flows while

359 garnet-pyroxene-rich rocks do not. 
Figure 1
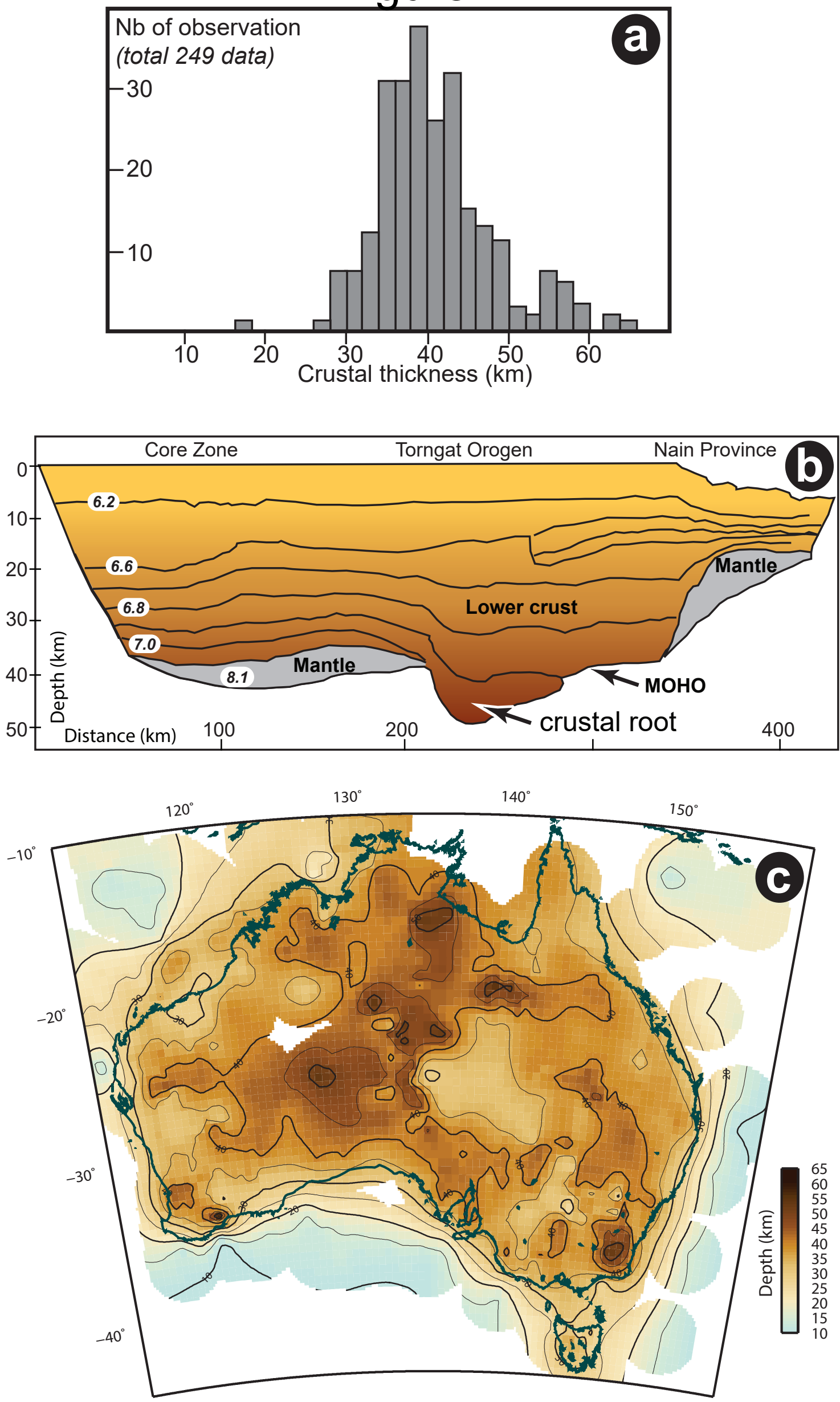

Figure 1 
Figure 2

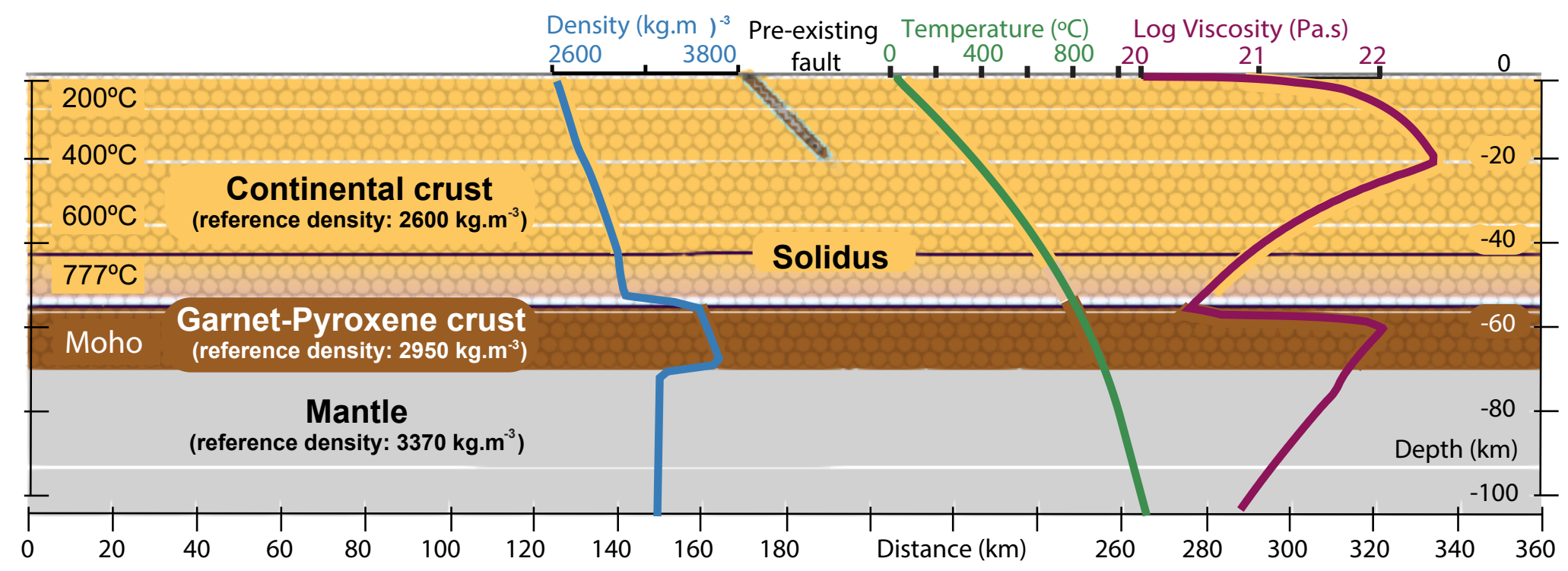

Figure 2 
Figure 3
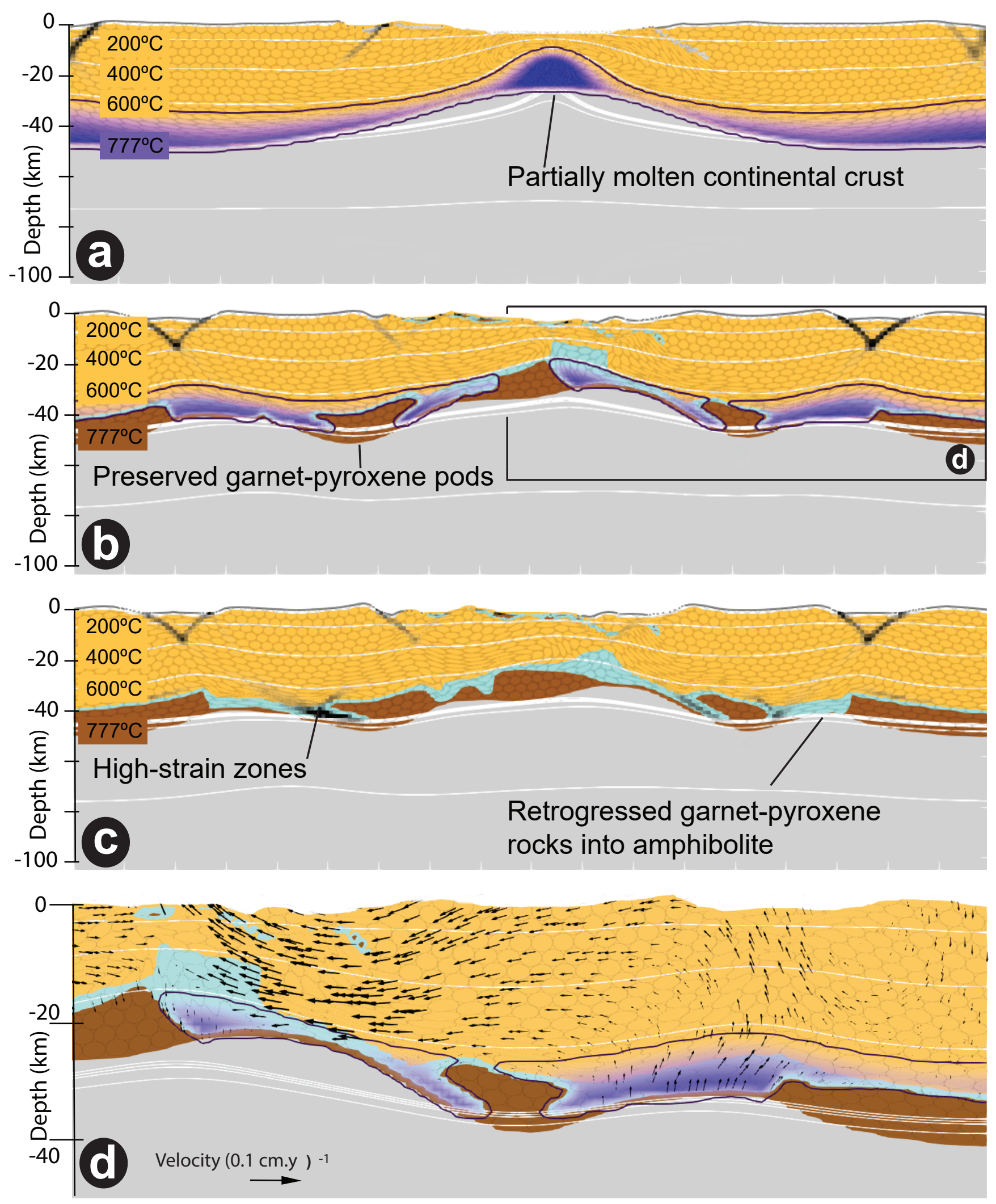

Figure 3 
1 Strain and retrogression partitioning explain long-term stability of crustal roots in stable continents

2 Bénédicte Cenki-Tok ${ }^{1,2}$, P.F. Rey ${ }^{2}$ and D. Arcay ${ }^{1}$

TABLE DR1. THERMAL AND MECHANICAL PARAMETERS

\begin{tabular}{|c|c|c|c|c|c|}
\hline Parameter & Continental Crust & Retrogressed Amphibolites & Garnet-Pyroxene CC & Upper Mantle & Fault \\
\hline Reference temperature $(\mathrm{K})$ & 293 & 293 & & & \\
\hline Dislocation creep viscous rheology & Wet quartzite ${ }^{\mathrm{a}}$ & Wet quartzite ${ }^{\mathrm{a}}$ & Dry Maryland Diabase ${ }^{b}$ & Wet dunite ${ }^{\mathrm{c}}$ & $0.1 *$ Wet quartzite ${ }^{\mathrm{a}}$ \\
\hline Reference density $\left(\mathrm{kg} \cdot \mathrm{m}^{-3}\right)$ & 2600 & 2600 & 2950 & 3370 & 2600 \\
\hline Thermal expansivity (K-1) & $-1.00 \mathrm{E}-04$ & $-1.00 \mathrm{E}-04$ & $-1.00 \mathrm{E}-04$ & $2.80 \mathrm{E}-05$ & $-1.00 \mathrm{E}-04$ \\
\hline Compressibility $\left(\mathrm{Pa}^{-1}\right)$ & $8.00 \mathrm{E}-11$ & $8.00 \mathrm{E}-11$ & - & - & $8.00 \mathrm{E}-11$ \\
\hline Heat capacity $\left(\mathrm{J} \mathrm{K}^{-1} \mathrm{~kg}^{-1}\right)$ & 1000 & 1000 & 1000 & 1000 & 1000 \\
\hline Thermal diffusivity $\left(\mathrm{m}^{2} \mathrm{~s}^{-1}\right)$ & $9 \mathrm{E}-07$ & $9 \mathrm{E}-07$ & $9 \mathrm{E}-07$ & $9 \mathrm{E}-07$ & $9 \mathrm{E}-07$ \\
\hline Latent heat of fusion $\left(\mathrm{kJ} \mathrm{kg}^{-1} \mathrm{~K}^{-1}\right)$ & 250 & 250 & 250 & - & 250 \\
\hline Radiogenic heat production $\left(\mathrm{W} \mathrm{m}^{-3}\right)^{\mathrm{d}}$ & $5.00 \mathrm{E}-07$ & $5.00 \mathrm{E}-07$ & $5.00 \mathrm{E}-07$ & - & $5.00 \mathrm{E}-07$ \\
\hline Melt fraction density change $e^{e}$ & 0.13 & 0.13 & - & - & 0.13 \\
\hline Solidus term $1(\mathrm{~K})$ & 923 & 923 & 1063 & - & 923 \\
\hline Solidus term $2\left(\mathrm{~K} \mathrm{~Pa}^{-1}\right)$ & $-1.20 \mathrm{E}-07$ & $-1.20 \mathrm{E}-07$ & $-1.20 \mathrm{E}-07$ & - & $-1.20 \mathrm{E}-07$ \\
\hline Solidus term $3\left(\mathrm{~K} \mathrm{~Pa}^{-2}\right)$ & $1.20 \mathrm{E}-16$ & $1.20 \mathrm{E}-16$ & $1.20 \mathrm{E}-16$ & - & $1.20 \mathrm{E}-16$ \\
\hline Liquidus term $1(\mathrm{~K})$ & 1423 & 1423 & 1563 & - & 1423 \\
\hline Liquidus term $2\left(\mathrm{~K} \mathrm{~Pa}^{-1}\right)$ & $-1.20 \mathrm{E}-07$ & $-1.20 \mathrm{E}-07$ & $-1.20 \mathrm{E}-07$ & - & $-1.20 \mathrm{E}-07$ \\
\hline Liquidus term $3\left(\mathrm{~K} \mathrm{~Pa}^{-2}\right)$ & $1.60 \mathrm{E}-16$ & $1.60 \mathrm{E}-16$ & $1.60 \mathrm{E}-16$ & - & $1.60 \mathrm{E}-16$ \\
\hline Friction coefficient & 0.44 & 0.44 & 0.44 & 0.44 & 0.44 \\
\hline Softened friction coefficient & 0.088 & 0.088 & 0.088 & 0.088 & 0.088 \\
\hline Cohesion (MPa) & 15 & 15 & 15 & 15 & 1.5 \\
\hline Softened cohesion (MPa) & 3 & 3 & 3 & 3 & 0.3 \\
\hline Pre-exponential factor $\left(\mathrm{MPa}^{-\mathrm{n}} \mathrm{s}^{-1}\right)$ & $5.00 \mathrm{E}-06$ & $5.00 \mathrm{E}-06$ & $5.05 \mathrm{E}-22$ & 70000 & $5.00 \mathrm{E}-06$ \\
\hline Stress exponent $(n)$ & 3 & 3 & 4.7 & 3 & 3 \\
\hline Activation energy $\left(\mathrm{kJ} \mathrm{mol}^{-1}\right)$ & 190 & 190 & 485 & 520 & 190 \\
\hline Activation volume $\left(\mathrm{m}^{3} \mathrm{~mol}^{-1}\right)$ & 0 & 0 & 0 & 0 & 0 \\
\hline Water fugacity & 0 & 0 & 0 & 0 & 0 \\
\hline Water fugacity exponent ${ }^{\mathrm{f}}$ & 0 & 0 & 0 & 0 & 0 \\
\hline Melt viscous softening factor & $1.00 \mathrm{E}-03$ & $1.00 \mathrm{E}-03$ & & & $1.00 \mathrm{E}-03$ \\
\hline Softening melt fraction interval & $0.2-0.3$ & $0.2-0.3$ & & & $0.2-0.3$ \\
\hline
\end{tabular}


Additional parameters:

Model Size: $360 \mathrm{~km}$ length (241 nodes, constant spacing) - $120 \mathrm{~km}$ thick (81 nodes, constant spacing) i.e. $15 \mathrm{~km}$ air-like material, $70 \mathrm{~km}$ crust,

$35 \mathrm{~km}$ upper mantle. The marker density is uniform (60 per grid cell).

A weak prismatic region dipping $45^{\circ} \mathrm{C}$ simulates a detachment in the upper crust

Basal heat flow is set at $0.015 \mathrm{~W} \cdot \mathrm{m}^{-2}$

Velocities tested: $1.8 \mathrm{~cm} \cdot \mathrm{y}^{-1}$ (fast) or $0.18 \mathrm{~cm} \cdot \mathrm{y}^{-1}$ (slow) and Isostasy is activated

Prograde amphibolite to garnet-pyroxene rock phase change set at $1050 \mathrm{~K}$

Retrograde garnet-pyroxene rock to amphibolite phase change set at $1050 \mathrm{~K}$ and $10-^{14} \mathrm{~s}^{-1}$ strain rate

Moho temperature at the start of the model is $883^{\circ} \mathrm{C}$

Solidus and liquidus are defined by a polynomial function of pressure $(\mathrm{P})$ :

$\mathrm{T}_{\mathrm{s}}=a_{0}+a_{1} \times \mathrm{P}+a_{2} \times \mathrm{P}^{2}, \mathrm{~T}_{1}=b_{0}+b_{1} \times \mathrm{P}+b_{2} \times \mathrm{P}^{2}$

The density of the continental crust changes according to $\mathrm{T}$ and $\mathrm{P}$ :

$\rho=\rho_{0} *(1+(\beta * \Delta \mathrm{P})-(\alpha * \Delta \mathrm{T}))$

Note that the presence of melt has an impact on density.

The maximum melt fraction is $30 \%$.

References:

a Parameters were derived from Brace and Kohlstedt (1980)

b Parameters were derived from Mackwell et al (1998)

c Parameters were derived from Brace and Kohlstedt (1980)

d Parameters were derived from Hasterok and Chapman (2011)

e Melt and other parameters were derived from Rey and Muller (2010)

f A zero value denotes that this effect on the viscous flow law is incorporated into the pre-exponential factor 
5 DR Figure1: Slow modeling results $\left(0.18 \mathrm{~cm} \cdot \mathrm{y}^{-1}\right.$ extension speed $)$ at an average strain rate of

$63 \mathrm{e}-16 \mathrm{~s}^{-1}$ and $25 \%$ extension. Colors are the same as in Fig. 2. Conditions for a, b and c

7 models are the same as in Fig. 3.

8 DR Figure2: Fast modeling results $\left(1.8 \mathrm{~cm} \cdot \mathrm{y}^{-1}\right.$ extension speed $)$ at an average strain rate of

$93 \mathrm{e}-15 \mathrm{~s}^{-1}$ and $25 \%$ extension. Colors are the same as in Fig 3. Variations of model shown on

10 Figure $3 \mathrm{~b}$ but a. only the prograde phase change is allowed. Retrogression does not occur,

11 and the crust, including the garnet-pyroxene layer, thins homogeneously. $b$. The strain rate

12 threshold for retrogression has been set to $10^{-13} \mathrm{~s}^{-1}$. Retrogression does not occur, and the

13 crust, including the garnet-pyroxene layer, thins homogeneously. c. The strain rate threshold

14 for retrogression has been set to $10^{-15} \mathrm{~s}^{-1}$, large portions of retrogressed and partially molten

15 crust are exhumed in the center of the model whereas the garnet-pyroxene layer is preserved

16 locally but strongly thinned.

\section{REFERENCES CITED:}

19 Brace, W.F., and Kohlstedt, D.L., 1980, Limits on lithospheric stress imposed by laboratory experiments: Journal of Geophysical Research, v. 85, p. 6248-6252.

Hasterok, D., Chapman, D., 2011. Heat production and geotherms for the continental lithosphere. Earth Planet. Sci. Lett. 307 (1), 5970. deformation of dry diabase with application to tectonics on Venus. Journal of Geophysical Research: Solid Earth, 103(B1), 975-984.

Rey, P.F., Muller, R.D., 2010. Fragmentation of active continental plate margins owing to the buoyancy of the mantle wedge. Nat. Geosci. 3 (4), 257-261. 


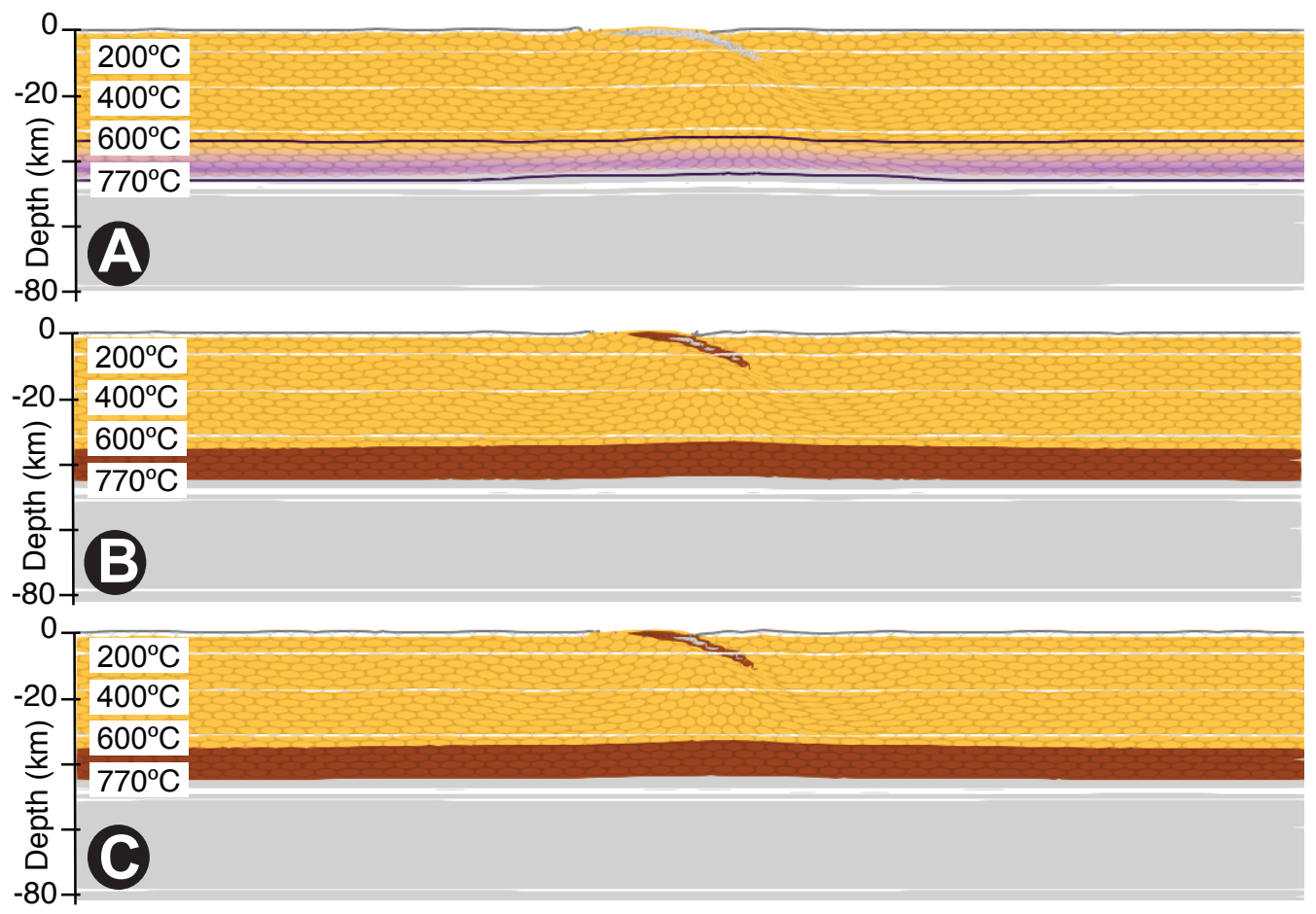

Supplementary Data Figure1 

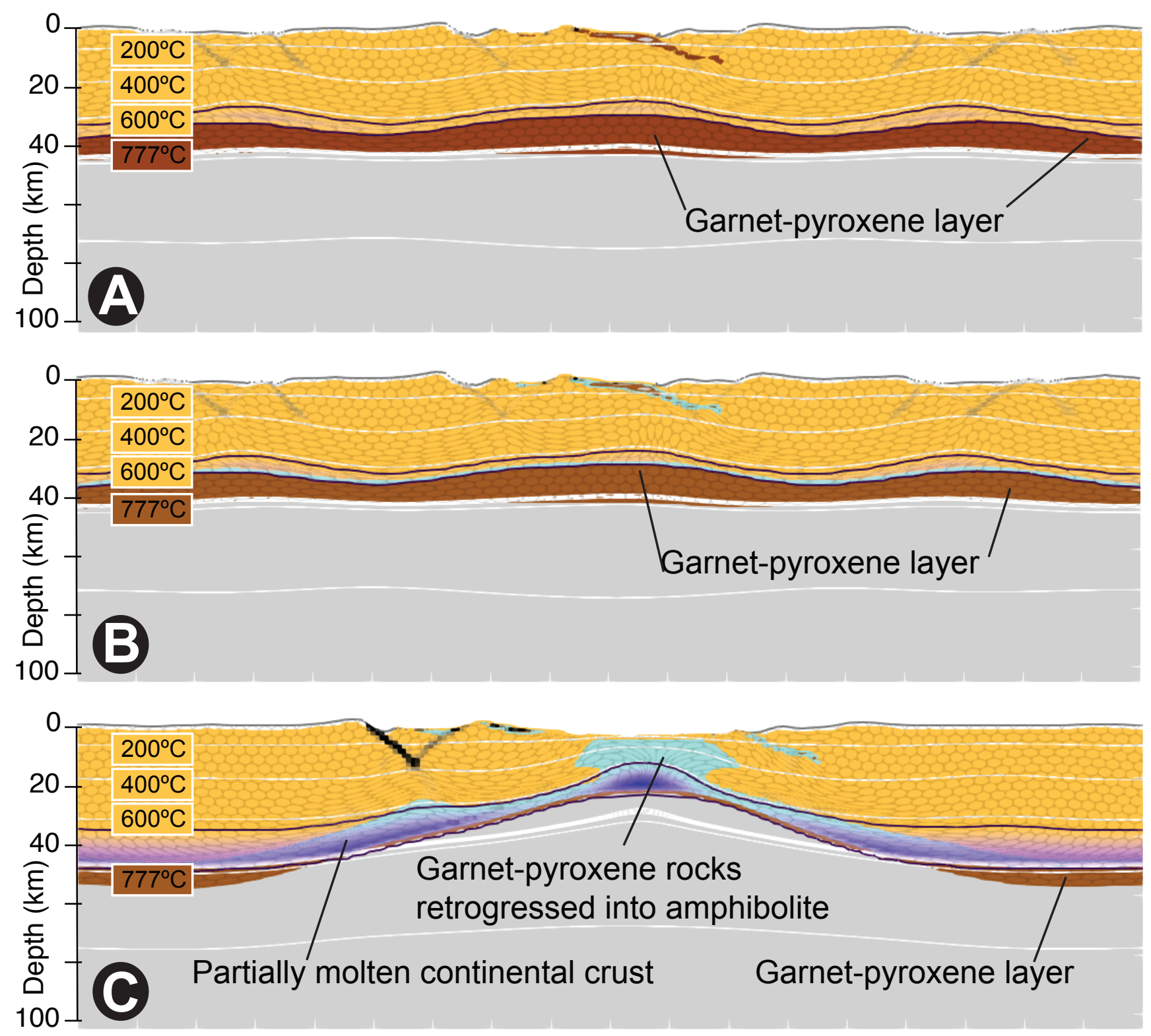

\section{Supplementary Data Figure2}

